\title{
Enzymatic Activity of Endophytic Bacterial Isolates of Jacaranda decurrens Cham. (Carobinha-do-campo)
}

\author{
Aysha Jussara Ivonilde Carrim, Edweis Cândida Barbosa and José Daniel Gonçalves \\ Vieira* \\ Laboratório de Biotecnologia e de Controle Biológico; Departamento de Microbiologia, Imunologia, Parasitologia \\ e Patologia; Instituto de Patologia Tropical e Saúde Pública; Universidade Federal de Goiás; Rua Delenda \\ Rezende de Melo, s/n; Setor Universitário; jvieira@iptsp.ufg.br; 74605-050; Goiânia - GO - Brasil
}

\begin{abstract}
The objectives of this work was to isolate endophytic bacteria from Jacaranda decurrens Cham. and screening of some enzymes of biotechnological interest. Ten (10) bacterial species were isolated and identified from the leaves and steams. All the isolates presented enzymatic activity, which was ranked as follows: proteolytic (60\%) and amilolytic activity (60\%), lipolytic (40\%), esterasic (40\%). However, cellulolytic and pectinolytic activities were not detected. This is the first report on the isolation and identification of endophytic bacteria from Jacaranda decurrens Cham.
\end{abstract}

Key words: Endophytic bacteria, Jacaranda decurrens, enzymes

\section{INTRODUCTION}

Endophytic microorganisms (fungi and bacteria) are those that inhabit inside of a plant at least in a period of its vital cycle, and are found in tissues such as leaves, branches and roots. Apparently, they do not cause any damage to the host, which distinguishes them from the phytopatogens microorganisms (Azevedo et al., 1999). Their presence implied a symbiotic interaction, in all the plants investigated until now (Azevedo et al., 2000). They were mentioned for the first time by Bary in $19^{\text {th }}$ century (Azevedo, 1998), gaining interest from 1970's. This interest is due to the possibility of these microorganisms producing pharmacologically active substances with biotechnological potential such as antitumor agents (Pestalotiopsis microspora, taxol), antifungal agents (Cryptosporiopsis criptocandina, quercine), besides producing factors of plant growth, toxins and enzymes, including some microorganisms being used as biological controllers of many diseases and plagues. (Araújo et al., 2002; Strobel, 2002; Azevedo, 1998; Stierle et al., 1993).

The importance of the microorganisms in enzyme production is due its high production capability, low cost and susceptibility to genetic manipulation. Actually, the enzymes of microbial origin have high biotechnological interest such as in the processing of foods, manufacturing of detergents, textiles, pharmaceutical products, medical therapy and in molecular biology (Pilnik and Rombouts, 1985; Falch, 1991; Rao et al., 1998). It is, therefore, necessary to find microorganisms that produce enzymes for specific substrate, with different requirements in temperature range, $\mathrm{pH}$ and presence of different

\footnotetext{
* Author for correspondence
} 
ions, for different production processes (Falch, 1991). The endophytic microorganisms occupy a relatively unexplored site in microorganism isolation so they can represent a new source in obtaining more enzymes with different potentialities.

The species Jacaranda decurrens Cham. is a shrub present in diverse physiognomies of the Brazilian Cerrado (Prado et al., 2002), popularly described as a medicinal plant that act in gynaecological infections, giardiae and amoeba's diseases and as an anti-syphilitic. The aim of this work was the isolation of endophytic microorganisms from Jacaranda decurrens Cham and the evaluation of enzyme production such as amylase, esterase, lipase, protease, pectinase and cellulose, by the isolates.

\section{MATERIALS AND METHODS}

\section{Isolation of the microorganisms}

Leaves and stems parts of one adult Jacaranda decurrens (about 2 years old) with healthy appearances were collected once from the vegetables garden of the Federal University of Goiás (UFG). The samples were disinfected according to Araújo et al. (2002), washed immediately with water for removal dried of dust and soil, in absorvent paper and cut in fragments with about $0.5 \mathrm{~cm}$ wide. The fragments were successively treated with ethanol $70 \%$ (1 min), sodium hypochloride $2-4 \%$ (available chlorine) for $4 \mathrm{~min}$. and exhaustively rinsed with sterilized distilled water. The fragments were then submitted in ultra-sound bathing $(40 \mathrm{KHz})$ for $10 \mathrm{~min}$., then rinsed again with sterilized distilled water for 3 times and submitted again to a bathing with ethanol $70 \%$ for 30 seconds and washed twice with sterilized distilled water. Aliquots of $1.0 \mathrm{~mL}$ of the last wash water were inoculated in $9.0 \mathrm{~mL}$ of nutrient broth in order to evaluate the effectiveness of the disinfection process.

After the disinfection, the samples were transferred to Petri dishes containing water-agar medium (1.8\% agar), nutrient agar with peptone, tryptic soy agar, King's media, starch-casein agar and ISP-2 agar with $1 \%$ of starch; all added with Nistatin $\left(200 \mu \mathrm{g} \mathrm{ml}^{-1}\right)$ and replicated four times. The plates were incubated at $30^{\circ} \mathrm{C}$ for 30 days (Azevedo et al., 2000). The colonies obtained were successively cut-up in each medium. This process was repeated five times and was accompanied by the description of the morphology and stained by Gram method. The isolates obtained were then grown in flasks containing nutrient agar and stored in refrigerator at $4^{\circ} \mathrm{C}$. At the same time, the isolates were maintained at $-20^{\circ} \mathrm{C}$ in cryogenic tubes containing glycerol at $50 \%$ in freezer.

\section{Identification of the microorganisms}

The morphological and stain identification was made through the Gram stain method and through the RYU reaction (Ryu, 1938, 1940). The isolates were then identified through commercial biochemical kits. For the identification of Enterobacteriaceae and Gram-negative non fermenters BBL Crystal TM Enteric/Nonfermenter (E/NF) Identification (ID) System with 30 reactions were used and for Gram-positive bacteria, BBL Crystal TM Gram-positive (GP) Identification (ID) System with 29 reactions were used.

\section{Determination of the enzymatic activity}

The productions of following enzymes were analysed: amylase, esterase, lipase, cellulase, protease and pectinase. The enzymatic activities were performed by initially growing the isolates in $\mathrm{BHI}$ (brain heart infusion) broth for $24 \mathrm{~h}$. at $30^{\circ} \mathrm{C}$. After that, aliquots of $100 \mu \mathrm{l}$ were inoculated on the specific culture media for each enzyme to be investigated. The cultures were incubated at $30^{\circ} \mathrm{C}$ during 96 h.. The Enzymatic Index (EI) was determinated within 24, 48, 72 and $96 \mathrm{~h}$. incubation, according to specific methodologies for each investigated enzyme. The Enzymatic Index (EI) was expressed by the relationship between the average diameter of the degradation halo and the average diameter of the colony growth (Hankin et al., 1971; Hankin and Anagnostakis, 1975).

\section{Determination of amilolytic activity}

The methodology used was described by Hankin and Anagnostakis (1975). The isolates were inoculated in nutrient agar (NA) with $0.2 \%$ of soluble starch $\left(\mathrm{g} \mathrm{l}^{-1}\right), \mathrm{pH}$ 6.0. After incubation, the cultures were treated under iodine vapours, which allowed the visualization of clear halos around the colonies.

\section{Determination of the esterasic activity}

The media used was as described by Sierra (1957), containing $\left(\mathrm{g} \mathrm{l}^{-1}\right)$ : peptone $10.0, \mathrm{NaCl} 5.0, \mathrm{CaCl}_{2}$ 
$2 \mathrm{H}_{2} \mathrm{O}$ 0.1, agar 18.0, pH 7.4. To the sterilized culture media, previously sterilized Tween 80 was added in a final concentration of $1 \%(\mathrm{v} / \mathrm{v})$. This medium was inoculated with the isolates and the presence of halos observed.

\section{Determination of the lipolytic activity}

A previously described methodology was used to determine the esterasic activity (Sierra 1957). In this determination, Tween 80 was substituted by Tween 20. The presence of clear halos around the colonies was observed.

\section{Determination of the proteolytic activity}

To determine the casein hydrolysis we used $\left(\mathrm{g} \mathrm{l}^{-1}\right)$ nutrient broth 8.0 , glucose 1.0 , and agar $18.0, \mathrm{pH}$ 7.4 (Vieira, 1999). After autoclaving, $15.0 \mathrm{ml}$ of skimmed milk, separately autoclaved was added. The microorganisms were inoculated and after the growth period $2.0 \mathrm{ml}$ of $\mathrm{HCl} 0.1 \mathrm{~mol} \mathrm{l}^{-1}$ was added to the plates and the presence of clear halos around the colonies were observed. In another method, the hydrolysis of gelatine was determined using the media of Frazier's gelatin agar, containig nutrient agar ( $\mathrm{pH} 7.0)$ and bacteriological gelatin $\left(4.0 \mathrm{~g} \mathrm{l}^{-1}\right)$. After incubation at $30^{\circ} \mathrm{C}$ for $72 \mathrm{~h}$., the plates were covered with Frazier's revealers (distilled water $100 \mathrm{ml}, \mathrm{HCl} 20.0 \mathrm{ml}$ and mercury dichloride 15.0 g) (Smibert and Krieg, 1994). The presence of a clear halo around the bacterial growth was observed.

\section{Determination of the cellulolytic activity}

Two methodologies were used for. In the first method, the cellulolytic activity was determined incubating the plates at $50^{\circ} \mathrm{C}$, over night, to facilitate the visualization of halo degradation of the cellulose (Stamford et al., 1998). The second method was according to Samanta et al. (1989).
The plates were incubated for eight days at $30^{\circ} \mathrm{C}$ and the presence of a clear halo around the bacterial growth was observed.

\section{Determination of the pectinolytic activity}

Two methodologies for the determination of this enzymatic activity were used. The first one was as described by Hankin et al. (1971). After the incubation period ( $96 \mathrm{~h}$.) the plates were recovered by a CTAB solution (hexadecyl trimethyl ammonium bromide) $1 \%(\mathrm{p} / \mathrm{v})$ and incubated at temperature for room. After this, the plates were washed with sterilized distilled water and the degradation of the pectin (clear halos around the colonies) was determined. Second method was of Andro et al. (1984). The plates were inoculated and incubated at $30^{\circ} \mathrm{C}$ for $96 \mathrm{~h}$. After this, $5.0 \mathrm{ml}$ of $\mathrm{HCl}\left(2 \mathrm{~mol} \mathrm{l}^{-1}\right)$ was added to the plates and the presence of clear halo around the colonies was indicative of the degradation of pectin. The experiments were performed using five repetitions and the results were analyzed statistically through the variance test and the averages compared by the test $t$, the tolerance level being set at $95 \%$, making of the program Statistica' 99, version 5.5, produced by StatSoft Inc.

\section{RESULTS}

\section{Endophytic isolates}

A total of 18 microorganisms were isolated from leaves and stem of Jacaranda decurrens. After the identification, the isolates were grouped in 10 species (Table 1) with predomination of the bacteria of the genera Bacillus (39\%), Pseudomonas (27.6\%), Corynebacterium (16.7\%), Actinomyces (11.1\%) and Staphylococcus (5.6\%).

Table 1 - Endophytic microorganisms isolated from Jacaranda decurrens

\begin{tabular}{lc}
\multicolumn{1}{c}{ Isolated microorganisms } & Number of Isolates $(\boldsymbol{\%})$ \\
\hline Actinomyces pyogenes & $2(11.11)$ \\
Bacillus circulans & $1(5.55)$ \\
Bacillus coagulans & $1(5.55)$ \\
Bacillus licheniformis & $2(11.11)$ \\
Bacillus megaterium & $2(11.11)$ \\
Corynebacterium aquaticum & $2(11.11)$ \\
Corynebacterium renale & $1(5.55)$ \\
Pseudomonas stutzeri & $5(27.77)$ \\
Staphylococcus sp & $1(5.55)$ \\
Bacillus sp & $1(5.55)$ \\
Total & $\mathbf{1 8 ( 1 0 0 )}$ \\
\hline
\end{tabular}




\section{Enzymatic activity}

In Table 2, the results of Enzymatic Index (EI) of the isolates tested are shown. Amylolytic activity was observed in the isolates CAR1, CAR3, CAR4, CAR5 CAR8 and CAR9, representing 60\% of the samples. The isolate CAR8 (EI 2.6) presented a significant difference at the level of $\rho<0.05$ for the test of $t$ of Student when compared to others. Esterasic and lipase activities were presents in $40 \%$ of the isolates (Table 2), isolate CAR7 presented EI of 6.2 and 3.7, respectively, with significant difference at the level of $\rho<0.05$ for the test of $t$ of Student when compared with the other isolates (Table 2).

It was observed that 30 and $60 \%$ of the isolates were able to hydrolyse casein and gelatin, respectively. Isolate CAR7 presented EI of 4.3 and 4.6 for casein and gelatin hydrolysis, respectively. These results presented significant difference at level of $\rho<0.05$ for the test of $t$ of Student when compared with the other isolates (Table 2). Activity for pectinase and cellulase was not observed among all of the species studied.

Table 2 - Enzymatic activity of the isolated microorganisms of Jacaranda decurrens ${ }^{\dagger}$.

\begin{tabular}{|c|c|c|c|c|c|c|}
\hline \multirow{2}{*}{\multicolumn{2}{|c|}{ Isolated microorganisms }} & \multicolumn{5}{|c|}{ Enzymatic Index (EI) ${ }^{*}$} \\
\hline & & \multirow{2}{*}{$\begin{array}{c}\text { Amylase } \\
1.2^{\mathrm{d}}\end{array}$} & \multirow{2}{*}{$\begin{array}{c}\begin{array}{c}\text { Esterase } \\
\text { (T80) }\end{array} \\
0\end{array}$} & \multirow{2}{*}{$\begin{array}{c}\begin{array}{c}\text { Lipase } \\
\text { (T20) }\end{array} \\
0\end{array}$} & \multirow{2}{*}{$\begin{array}{l}\begin{array}{c}\text { Protease } \\
(\text { Casein) }\end{array} \\
2.0^{\mathrm{c}}\end{array}$} & \multirow{2}{*}{$\begin{array}{r}\begin{array}{c}\text { Protease } \\
\text { (Gelatin) }\end{array} \\
2.6^{\mathrm{b}}\end{array}$} \\
\hline Actinomyces pyogenes & CAR1 & & & & & \\
\hline Bacillus circulans & CAR2 & 0 & 0 & 0 & 0 & $4.4^{\mathrm{a}}$ \\
\hline Bacillus coagulans & CAR3 & $1.7^{\mathrm{c}}$ & 0 & 0 & 0 & $2.0^{\mathrm{c}}$ \\
\hline Bacillus licheniformis & CAR4 & $1.8^{\mathrm{b}, \mathrm{c}}$ & 0 & 0 & 0 & $1.9^{\mathrm{c}}$ \\
\hline Bacillus megaterium & CAR5 & $2.2^{\mathrm{a}, \mathrm{b}}$ & 0 & 0 & $3.1^{\mathrm{b}}$ & $2.8^{\mathrm{b}}$ \\
\hline Corynebacterium aquaticum & CAR6 & 0 & $3.0^{\mathrm{b}}$ & $2.9^{\mathrm{b}}$ & 0 & 0 \\
\hline Corynebacterium renale & CAR7 & 0 & $6.2^{\mathrm{a}}$ & $3.7^{\mathrm{a}}$ & $4.3^{\mathrm{a}}$ & $4.6^{\mathrm{a}}$ \\
\hline Pseudomonas stutzeri & CAR8 & $2.6^{\mathrm{a}}$ & $3.2^{\mathrm{b}}$ & $2.4^{\mathrm{c}}$ & 0 & 0 \\
\hline Staphylococcus sp & CAR9 & $1.8^{\mathrm{b}, \mathrm{c}}$ & $2.8^{\mathrm{b}}$ & $2.9^{\mathrm{b}}$ & 0 & 0 \\
\hline Bacillus sp & CAR10 & 0 & 0 & 0 & 0 & 0 \\
\hline
\end{tabular}

* The enzymatic index represents the halo diameter of degradation/diameter of colony in $\mathrm{cm}$. Averages followed by the same letter don't differ among themselves (test $t$ of Student, $\rho<0.05$ ).

$\dagger$ An average of five repetitions.

\section{DISCUSSION}

Bacteria are common inhabitants on the surface as well as inside tissues of the plants, exerting various effects on the development of these (Selosse et al., 2004). The bacteria that live in the interior of plants without causing diseases to their hosts are called endophytic (Petrini et al., 1989; Azevedo et al., 2000). Endophytic microorganisms have been isolated from different types of vegetation such as grass (Naffaa et al., 1998), corn (Araújo et al., 2000; McInroy and Kloepper, 1995), Eriaceae (Petrini, 1984), cotton (McInroy and Kloepper, 1995), bryophytes (Costa et al., 2001), Solanum lycocarpum (Maitan, 1998) and agricultural crops (Halmann et al., 1997). Studies for the isolation and characterization of endophytic microorganisms of native plant specimens from Brazilian Cerrado biome are rare. This is therefore, the first report of the isolation, identification and characterization of endophytic microorganisms of the specimen of the Bignoniaceae family, Jacaranda decurrens Cham.

The results obtained showen the common phenomenon of association between the microorganisms and plants (Azevedo, 1998). A variety of genera and species of bacteria, were observed. Apparently, this is second report for the isolation of Staphylococcus sp as endophytic bacteria (Stamford et al., 1998).

The research with endophytic microorganisms is more focused in species with economic value such as corn, soy, grasses and others (Petrini, 1984; McInroy and Kloepper, 1995; Halmann et al., 1997; Naffaa et al., 1998; Araújo et al., 2000; Costa et al., 2001) or species capable of producing antimicrobials, as Taxus wallachiana (Yang et al., 1994).

The method of the radial diffusion in solid media indicated the activity in qualitative form, directly correlating the diameters of the halo of degradation and the colony (Enzymatic Index) (Lin et al., 1991). The Enzymatic Index is a 
practical tool that facilitates and speeds the selection and the comparison of the enzymatic production of different isolates microbial, once in this index direct consideration the correlation are taken between the size of the halo and the degradation capacity of the microorganisms (Lin et al., 1991; Fungaro and Maccheroni 2002). Fungaro and Maccheroni (2002) suggested that Enzymatic Index larger than 1.0 were indicative of excretion of enzymes.

It was observed that all the isolates possessed at least one enzymatic activity tested (Table 2).The amylolytic activity was observed for isolates $B$. coagulans CAR3, B. licheniformis CAR4, $B$. megaterium CAR5, Act. pyogenes CAR1 and $P$. stutzeri CAR8. So far only Ps. stutzeri, B. megaterium and $B$. licheniformis have been suggested as producers of extracellular amylase (Schmidt and John, 1979; Rivera et al., 2003). These results suggested that isolates Act. pyogenes CAR1 and $B$. coagulans CAR3, produced extracellular amylolytic enzymes.

Among the producers of esterases and lipases, Bacillus as well as Ps. stutzeri have been described (Jung et al., 2003; Ruiz et al., 2002). Species of Corynebacterium have not been described as potentials producers of esterases and lipases (Hou and Jonhnston, 1992), however, in the results obtained it was observed that the isolate Coryne. renale CAR 7 demonstrated the best $\mathrm{EI}$ for esterase and lipase (6.2 and 3.7, respectively), suggesting the potential of this isolate as producer of these enzymes (Jaeger and Eggert, 2002). The best proteolytic production was observed in gelatinase producing bacteria compared to the casein producers, although CAR1, CAR5 and CAR7 produced both enzymes. Apparently bacteria produced unspecific proteases capable to hydrolyze both casein and gelatin. CAR2, CAR3 and CAR4 hydrolyzed gelatin only, suggesting that this enzyme was more specific for collagen.

The presence of proteolytic activity in B. circulans CAR 2, B. coagulans CAR3, B. licheniformis CAR4, B. megaterium CAR5 and Coryne. renale CAR7 confirmed that some species of Bacillus and Corynebacterium tended to synthesize proteolytic enzymes during the sporulation process (Ponnuraj et al., 1999; Kamasaka et al., 2002), as observed in this study. Ryttersgaard et al.(2004) mentioned pectinase production by $B$. liqueniformis and Sorian et al. (2005) for Bacillus sp, but in this work these species did not show the same enzyme production, despite using two different growth media.

This is the first report on the isolation of endophytic microorganisms with production of enzymatic activity in solid media. Jacaranda decurrens Cham as the native plant of Brazilian Cerrado and used in popular phytoterapy, it revealed new endophytic source with applicable biotechnological potential in different areas such as in the nutrition, detergent, paper, pharmaceutical, textile and leather industries.

\section{RESUMO}

O objetivo deste trabalho foi isolar bactérias endofíticas de Jacaranda decurrens Cham. e selecionar algumas enzimas de interesse biotecnológico. Dez espécies de bactérias foram isoladas e identificadas de caule e folhas. Todos os isolados de apresentaram atividade enzimática, e a maior predominância foi de atividade proteolítica $(60 \%)$ e atividade amilolítica (60\%), seguidas atividades lipolítica (40\%) e esterásica (40\%). Contudo, as atividades celulolítica e pectinolítica não foram detectadas. Este é o primeiro relato de isolamento e identificação de bactérias presentes em Jacaranda decurrens Cham.

\section{ACKNOWLEDGEMENTS}

The authors acknowledge $\mathrm{CNPq}$ for the concession of master's degree scholarship to the first author, FUNAPE/UFG and to the Program of Masters degree in Tropical Medicine (IPTSP/UFG) for the financial aid. We thank's Prof. Dr. José Realino de Paula for helping in the collection and classification of plant species and to Prof. Dra. Fabiana Cristina Pimenta, Prof. Dr. José Cirano Ulhôa, Vanda Pina Martins and Prof. Ms. Valéria Maitan for the suggestions in the composition of this manuscript.

\section{REFERENCES}

Andro, T.; Chambost, J. P.; Kotoujansky, A.; Cattaneo, J.; Bertheau, Y.; Barras, F.; Gijsegem, F. Van and Coleno, A. (1984), Mutants of Erwinia chrysanthemi defective in secretion of pectinase and cellulase. Journal of Bacteriology, 160, 1199-1203. 
Araújo, J. M.; Silva, A. C. and Azevedo, J. L. (2000), Isolation of endophytic actinomycetes from roots and leaves of maize (Zea mays L.). Brazilian Archives of Biology and Technology, 43, 447-451.

Araújo, L. W.; Lima, A. O. S; Azevedo, J. L.; Marconi, J.; Sobral, J. K. and Lacava, P. T. (2002), Manual: isolamento de microrganismos endofíticos. Piracicaba: USP. 86 pp.

Azevedo, J. L. (1998), Microrganismos endofíticos. In: Melo, I. S. and Azevedo, J. L. (Eds.). Ecologia microbiana. Jaguariúna: Embrapa Meio Ambiente. pp. 117-137.

Azevedo, J. L.; Araújo, W. L. and Maccheroni Jr., W. (1999), Importância dos microrganismos endofíticos no controle de insetos. In: Melo, I. S. and Azevedo, J. L. (Eds.). Controle Biológico. Jaguariúna: Embrapa Meio Ambiente. pp. 57-91. v. 3.

Azevedo, J. L.; Maccheroni Jr.; W.; Pereira, J. O. and Araújo, W. L. (2000), Endophytic microorganisms: a review on insect control and recent advances on tropical plants. EJB: Eletronic Journal of Biotechnology, 3. Available in: http://www.ejb.org/ content/vol3/isse1/full/3/4.

Costa, J. L.; Paulsrud, P.; Rikkinen, J. and Lindblad, P. (2001), Genetic diversity Nostoc symbionts endophytically associated with two bryophyte species. Applied Environmental Microbiology, 67, 4393-4396.

Falch, E. A. (1991), Industrial enzymes - developments in production and application. Biotechnology Advance, 9, 643-658.

Fungaro, M. H. P. and Maccheroni Jr., W. (2002), Melhoramento genético para produção de enzimas aplicadas à Indústria de Alimentos. In: Melo, I. S.; Valadares-Inglis, M. C.; Nass, L. L. and Valois, A.C.C. (Eds.). Recursos Genéticos e MelhoramentoMicrorganismo. Jaguariúna: Embrapa Meio Ambiente. pp. 426-453.

Hallmann, J.; Quadt-Hallmann, A.; Mahaffee, W. F. and Kloepper, J. W. (1997), Bacterial endophytes in agricultural crops. Canadian Journal Microbiology, 43, 895-914.

Hankin, L. and Anagnostakis, S. L. (1975), The use of solid media for detection of enzyme production by fungi. Mycologia, 67, 597-607.

Hankin, L.; Zucker, M. and Sands, D. C. (1971), Improved solid medium for the detection and enumeration of pectolytic bacteria. Applied of Microbiology, 22, 205-209.

Hou, C. T. And Johnston, T. M. (1992), Screening of lipase activities with cultures from the agricultural research service culture collection. Journal American Oil Chemist's Society, 69 : (11), 1088-1097.

Jaeger, K. E. and Eggert, T. (2002), Lipases for biotechnology. Current Opinion in Biotechnology, 13, 390-397.
Jung, Y. J.; Lee, J. K.; Sung, G. G.; Oh, T. K. and Kim, H. K. (2003), Nonionic detergent-induced activation of an esterase from B. Megaterium 20-1. Journal of Molecular Catalysis B: Enzimatic, 26, 223-229.

Kamasaka, H.; Sagimoto, K.; Takata, H.; Nishimura, T. and Kuirk, T. (2002), Bacillus stearothermophilus Neopullulase selective hydrolysis of amulose to maltose in the presence of amylopectin. Applied. Environmental Microbiology, 6, 1658-1664.

Lin, J. E; Chang, D. C. N. and Shen, G. J. (1991), Correlations among several screening methods used for identificatifying wood-decay fungi that can degrade toxic chemicals. Biotechniques, 5, 275-280.

Maitan, V. R. (1998), Isolamento e caracterização de Actinomicetos endofíticos isolados de Solanum lycocarpum (lobeira). Msc. Thesis. Universidade Federal de Goiás, Brazil.

McInroy, J. A. and Kloepper, J. W. (1995), Survey of indigenous bacterial endophytes from cotton and sweet corn. Plant and Soil, 173, 337-342.

Naffaa, W.; Ravel, C. and Guillanumin, J. J. (1998), Nutritional requirements for growth of fungal endophytes of grasses. Canadian Journal Microbiology, 44, 231-237.

Petrini, O. (1984), Endophytic fungi in British Ericaceae. A preliminary study. Translaction of the Britsh Mycological Society, 83, 510-512.

Petrini, L. E; Petrini, O. and Laflamme, G. (1989), Recovery of endophytes of Abiens balsamea from needles and galls of Paradiplosis tumiflex. Phytoprotection, 70, 97-103.

Pilnik, W. and Rombouts, F. M. (1985), Polysaccharides and food processing. Carbohydrate Research, 142, 93-105.

Ponnuraj, K.; Nessi, C.; Setlow, P. and Jedrzejas, M. J. (1999), Structural studies of a novel germination protease from spores of Bacillus megaterium. Journal of Structural Biology, 125, 19-24.

Prado, D. S.; Oliveira Jr.; O. P. and Oliveira, T. B. (2002), Controle de Qualidade e doseamento de açúcares redutores de amostras de Jacaranda decurrens Cham. (carobinha) comercializada na cidade de Goiânia. Monography, Faculdade de Farmácia, Universidade Federal de Goiás, Brazil.

Rao, M. B.; Tanksale A. M.; Ghatge M. S. and Deshpand, V. V. (1998), Molecular and Biotechnological Aspects of Microbial Proteases. Microbiology and Molecular Biology Reviews, 62, 597-635.

Rivera, M. H.; Lopez-Munguia, A.; Soberon, X. and Saab-Rincom, G. (2003), Alpha-amylase from Bacillus licheniformis mutants near to the catalytic site: effects on hidrolytic and transglycosylation activity. Protein Engineering, 16 : (7), 505-14.

Ruiz, C.; Blanco, A.; Pastor, F. I. J. and Diaz, P. (2002), Analysis of Bacillus megaterium lipolytic system and cloning of LipA, a novel subfamily I.4. bacterial lipase. FEMS - Microbiology Letters, 212, 263-267. 
Ryttersgaard, C.; Nours, J. L.; Leggio, L. L.; Jørgensen, C. T.; Christensen, L. L. H.; Bjørnvad, M. and Larsen, M. (2004), The structure os endo-beta-1,4galactanse from Bacillus licheniformis in complex with two oligosaccharide products. Journal of Molecular Biology, 341, 107-117.

Ryu, E. (1938), On the gram-differentiation of bacteria by simplest method. Journal of the Japanese Society for Veterinary Science, 17, 31.

Ryu, E. (1940), A simple method for differentiation between Gram-positive and Gram-negative organisms without staining. Kitazato Archives of Experimental Medicine, 17, 58-63.

Samanta, R.; Pal, D. and Sem, S. P. (1989), Production of hydrolases by $\mathrm{N}_{2}$-fixing microorganisms. Biochemie und Physiologie der Pflanzen, 185, 75-81.

Schmidt, J. and John, M. (1979), Starch metabolism in Pseudomonas stuteri. I. Studies on matotetraoseforming amylase. Biochimica et Biophysica Acta (BBA) - Enzymology, 566 : (1), 88-99.

Selosse, M. A., Baudoin, E. and Vandenkoornhuyse, P. (2004), Symbiotic microorganisms, a key for ecological success and protection of plants. Comftes Rendus Biologies, 327, 639-648.

Sierra, G. A. (1957), A simple method for the detection of lypolytic activity of microorganisms and some observations on the influence of the contact between cells and fatty substracts. Antonine van Leeuwenhoeck, 28, 15-22.

Smibert, R. M. and Krieg, N. R. (1994), Phenotypic characterization. In: Gerhardt, P.; Murray, R. G. E.; Wood, W. A. and Krieg, N. R. (Eds.). Methods for general and molecular bacteriology. Washington, USA. pp. 607-654.
Soriano, M.; Diaz, P. and Pastor, F. I. (2005), Pectinolytic Systems of two aerobic sporogenous bacterial strains with high activity on pectin. Current Microbiology, 50, 114-118.

Stamford, T. L.; Araújo, J. M. and Stamford, N. P. (1998), Atividade enzimática de microrganismos isolados de jacatupé (Pachyrhizus erosos L. Urban). Ciência e Tecnologia dos Alimentos, 18 : (4), 382-385.

Stierle, A.; Strobel, G. and Stierle, D. (1993), Taxol and taxane production by Taxomyces andreanae an endophytic fungus of Pacific yew. Science, 260, 214-216.

Strobel, G. A. (2002), Rainforest endophytes and bioactive products. Critical Reviews in Biotechnology, 22 : (4), 315-333.

Vieira, J. D. G. (1999), Purificação e caracterização de uma $\alpha$-amilase de Streptomyces sp. $\mathrm{PhD}$. Thesis, Universidade de São Paulo, Brazil.

Yang, X.; Strobel, G.; Stierle, A.; Hess, W.M.; Lee, J. and Clardy, J. (1994), A fungal endophyte-tree relationship: Phoma sp. In Taxus wallachiana. Plant Sci., 102, 1-9.

Received: December 15, 2004; Revised: April 18, 2005; Accepted: March 01, 2006. 